Contract No. and Disclaimer:

This manuscript has been authored by Savannah River Nuclear Solutions, LLC under Contract No. DE-AC09-08SR22470 with the U.S. Department of Energy. The United States Government retains and the publisher, by accepting this article for publication, acknowledges that the United States Government retains a non-exclusive, paid-up, irrevocable, worldwide license to publish or reproduce the published form of this work, or allow others to do so, for United States Government purposes. 


\title{
INCORPORATION OF MONO SODIUM TITANATE AND CRYSTALLINE SILICOTITANATE FEEDS IN HIGH LEVEL NUCLEAR WASTE GLASS
}

\author{
K.M. Fox, F.C. Johnson, and T.B. Edwards \\ Savannah River National Laboratory \\ Aiken, SC 29808 USA
}

\section{ABSTRACT}

Four series of glass compositions were selected, fabricated, and characterized as part of a study to determine the impacts of the addition of Crystalline Silicotitanate (CST) and Monosodium Titanate (MST) from the Small Column Ion Exchange (SCIX) process on the Defense Waste Processing Facility (DWPF) glass waste form and the applicability of the DWPF process control models. All of the glasses studied were considerably more durable than the benchmark Environmental Assessment (EA) glass. The measured Product Consistency Test (PCT) responses were compared with the predicted values from the current DWPF durability model. One of the KT01-series and two of the KT03-series glasses had measured PCT responses that were outside the lower bound of the durability model. All of the KT04 glasses had durabilities that were predictable regardless of heat treatment or compositional view. In general, the measured viscosity values of the KT01, KT03, and KT04-series glasses are well predicted by the current DWPF viscosity model. The results of liquidus temperature $\left(\mathrm{T}_{\mathrm{L}}\right)$ measurements for the KT01-series glasses were mixed with regard to the predictability of the $T_{L}$ for each glass. All of the measured $T_{L}$ values were higher than the model predicted values, although most fell within the 95\% confidence intervals. Overall, the results of this study show a reasonable ability to incorporate the anticipated SCIX streams into DWPF-type glass compositions with $\mathrm{TiO}_{2}$ concentrations of $4-5 \mathrm{wt} \%$ in glass.

\section{INTRODUCTION}

The Savannah River Site (SRS) Tank Farm will begin a process referred to as Small Column Ion Exchange (SCIX) to disposition salt solution in fiscal year 2014. In the first step of the process, salt solution retrieved from various waste tanks will be struck with Monosodium Titanate (MST) to remove key actinides. The salt solution will then be processed using Rotary Micro Filtration (RMF) to remove the MST and any insoluble solids. The MST and insoluble solids will accumulate on the bottom of Tank 41. The filtrate from RMF will be fed to ion exchange columns, also in Tank 41, to remove the ${ }^{137}$ Cs using Crystalline Silicotitanate (CST) resin. The decontaminated salt solution from SCIX will be sent to the Saltstone Facility for immobilization in grout. The ${ }^{137}$ Cs-laden CST resin will be sluiced and ground for particle size reduction, then sent to the Defense Waste Processing Facility (DWPF) for immobilization in glass. These processes mirror the current disposition paths for streams associated with the Salt Waste Processing Facility (SWPF), which is under construction.

The MST and insoluble solids from Tank 41 will periodically be transferred to a sludge batch preparation tank (e.g., Tank 42 or Tank 51) as part of the High Level Waste (HLW) sludge batch preparation process for DWPF. The ground, ${ }^{137}$ Cs-laden CST material (hereafter referred to simply as CST) from SCIX will be periodically transferred to Tank 40 prior to being processed at DWPF. Periodic additions of CST to Tank 40 
would result in a changing composition of each sludge batch as it is processed since Tank 40 serves as the feed tank for the DWPF. Work is currently in progress to determine the feasibility of dropping the ground CST into Tank 41. If ground CST can be dropped into Tank 41 (depending on heat loading issues, among others), the CST would be sent to Tank 42 or Tank 51 using an existing transfer line. Therefore, the studies of SCIX impacts on DWPF glass formulation will encompass scenarios where the CST is sent to either Tank 40 or a sludge batch preparation tank.

The MST and CST from the SCIX process will significantly increase the concentrations of $\mathrm{Nb}_{2} \mathrm{O}_{5}, \mathrm{TiO}_{2}$, and $\mathrm{ZrO}_{2}$ in the DWPF feed. Other constituents of MST and CST $-\mathrm{Na}_{2} \mathrm{O}$ and $\mathrm{SiO}_{2}$ - are already present in high concentrations in DWPF glass; thus their influences are well understood. The increased concentrations of $\mathrm{Nb}_{2} \mathrm{O}_{5}, \mathrm{TiO}_{2}$, and $\mathrm{ZrO}_{2}$ will likely have some impact on the properties and performance of the DWPF glass product. Properties such as the liquidus temperature, viscosity, and rate of melting of the glass may be impacted. The performance of the glass, particularly its chemical durability as it pertains to repository acceptance requirements, may also be impacted. The DWPF uses a set of semi-empirical and first-principles models referred to as the Product Composition Control System (PCCS) ${ }^{1}$ to predict the properties and performance of a glass based on its composition since it is not possible to measure these attributes during processing. The objective of this study is to evaluate the impacts of the SCIX streams on the properties and performance of the DWPF glass product and on the applicability of the current process control models.

Previous studies have provided data on the potential impacts of MST and CST specifically on DWPF-type glasses. Edwards and Harbour completed a series of studies on the coupling of CST and MST with Purex and HM sludges for DWPF processing in $1999 .^{2-6}$ All of the glasses studied had very good measured durability values, although there were minor issues with the predictions of the durability model and the majority of the glasses failed the homogeneity constraint. ${ }^{6}$ The glasses generally had estimated liquidus temperatures that would be acceptable for DWPF processing. The viscosities of the glasses produced with CST and the Purex sludge were acceptable for processing but not well predicted. The viscosities of the glasses fabricated with CST and HM sludge were too high for processing but were better predicted.

Fox and Edwards recently performed a paper study evaluation using updated projections for sludge batch compositions and SCIX CST and MST addition rates. ${ }^{7}$ This study found that, as a result of the updated composition projections, several viable options were predicted to be available for incorporation of the SCIX streams into either Tank 40 or a sludge batch preparation tank. Transfer of the CST to a sludge batch preparation tank was the preferred option since it allowed more compositional flexibility for frit development while maintaining sufficient projected operating windows. The report again identified several assumptions and limitations associated with the current PCCS models, and recommended that these be further evaluated.

This study focuses on addressing the assumptions made during the paper studies, and will provide data for further evaluation of model performance. 


\section{EXPERIMENTAL PROCEDURE}

Selection of Glass Compositions

Two series of glass compositions, identified as the KT01-series and the KT02-series, were developed for the first portion of the study. Composition projections developed during the paper study evaluation of the addition of the SCIX streams were used as the basis for the two series, ${ }^{7}$ as shown in Table 1 . The KT01-series compositions were derived with the intent of investigating the impact of individual glass components on the retention of $\mathrm{TiO}_{2}$. The concentrations of $\mathrm{Al}_{2} \mathrm{O}_{3}, \mathrm{~B}_{2} \mathrm{O}_{3}, \mathrm{Fe}_{2} \mathrm{O}_{3}, \mathrm{~K}_{2} \mathrm{O}, \mathrm{Li}_{2} \mathrm{O}, \mathrm{Na}_{2} \mathrm{O}$, and $\mathrm{SiO}_{2}$ were adjusted from the baseline composition to determine whether these changes would affect the ability of the glass to accommodate increased $\mathrm{TiO}_{2}$ concentrations. The $\mathrm{U}_{3} \mathrm{O}_{8}$ and $\mathrm{ThO}_{2}$ components were removed so that the glasses could be handled in a nonradioactive laboratory. The concentration of $\mathrm{TiO}_{2}$ was forced to an elevated value of 8 wt $\%$ for each composition. The remaining components were then normalized to give a total of $100 \mathrm{wt} \%$. These steps resulted in 13 glass compositions for the KT01-series, and their target compositions are available elsewhere. ${ }^{8}$

Table 1. Projected Average Concentrations (wt \%) of Glass Components in Out-Year Processing at DWPF with SCIX Streams.

\begin{tabular}{|c|c|c|c|}
\hline Oxide & Average & Oxide & Average \\
\hline $\mathrm{Al}_{2} \mathrm{O}_{3}$ & 5.69 & $\mathrm{MnO}$ & 1.30 \\
\hline $\mathrm{B}_{2} \mathrm{O}_{3}$ & 4.80 & $\mathrm{Na}_{2} \mathrm{O}$ & 15.03 \\
\hline $\mathrm{BaO}$ & 0.08 & $\mathrm{Nb}_{2} \mathrm{O}_{5}$ & 0.43 \\
\hline $\mathrm{CaO}$ & 1.01 & $\mathrm{NiO}$ & 0.36 \\
\hline $\mathrm{Ce}_{2} \mathrm{O}_{3}$ & 0.21 & $\mathrm{PbO}$ & 0.12 \\
\hline $\mathrm{Cr}_{2} \mathrm{O}_{3}$ & 0.11 & $\mathrm{SO}_{4}{ }^{2-}$ & 0.08 \\
\hline $\mathrm{CuO}$ & 0.03 & $\mathrm{SiO}_{2}$ & 47.52 \\
\hline $\mathrm{Fe}_{2} \mathrm{O}_{3}$ & 12.05 & $\mathrm{ThO}_{2}$ & 0.23 \\
\hline $\mathrm{K}_{2} \mathrm{O}$ & 0.07 & $\mathrm{TiO}_{2}$ & 2.74 \\
\hline $\mathrm{La}_{2} \mathrm{O}_{3}$ & 0.08 & $\mathrm{U}_{3} \mathrm{O}_{8}$ & 2.53 \\
\hline $\mathrm{Li}_{2} \mathrm{O}$ & 4.80 & $\mathrm{ZnO}$ & 0.05 \\
\hline $\mathrm{MgO}$ & 0.15 & $\mathrm{ZrO}_{2}$ & 0.52 \\
\hline
\end{tabular}

A similar process was used to develop compositions for the KT02-series glasses. The intent was to again identify any impact of individual glass components on the retention of $\mathrm{TiO}_{2}$. The only difference from the KT01-series was the increase in $\mathrm{TiO}_{2}$ concentrations from $8 \mathrm{wt} \%$ to $12 \mathrm{wt} \%$ for each of the glass compositions, with a subsequent normalization of the other components to $100 \mathrm{wt} \%$. The KT02-series glasses were not characterized as thoroughly as the KT01-series glasses since their $\mathrm{TiO}_{2}$ concentrations were quite high. As will be described below, X-ray Diffraction (XRD) was used to identify any obvious changes in the crystallization behavior of these glasses after the $\mathrm{CCC}$ when $\mathrm{TiO}_{2}$ concentrations were high, but chemical properties were not determined.

The KT03-series of compositions was developed to further investigate the potential impacts of the addition of the SCIX streams on glass properties. The average glass composition given in Table 1 was again used, with adjusted values (minimums and 
maximums) for the concentrations of $\mathrm{Al}_{2} \mathrm{O}_{3}, \mathrm{~B}_{2} \mathrm{O}_{3}, \mathrm{Fe}_{2} \mathrm{O}_{3}, \mathrm{~K}_{2} \mathrm{O}, \mathrm{Li}_{2} \mathrm{O}, \mathrm{Na}_{2} \mathrm{O}$, and $\mathrm{SiO}_{2}$ to identify any impacts of these individual components on the behavior of $\mathrm{TiO}_{2}$ in the glass. The $\mathrm{TiO}_{2}$ concentrations were fixed at an elevated value of $8 \mathrm{wt} \%$. The other major constituents of CST, $\mathrm{Nb}_{2} \mathrm{O}_{5}$ and $\mathrm{ZrO}_{2}$, were fixed at elevated concentrations of $3 \mathrm{wt} \%$ and $2.5 \mathrm{wt} \%$, respectively, to identify any interactive effects with $\mathrm{TiO}_{2}$. This resulted in 13 target compositions for the KT03-series glasses, which are available elsewhere. ${ }^{8}$

The basis for the KT04-series compositions was changed from the average glass composition used previously (Table 1) to projections of individual sludge batches incorporating the SCIX streams. These projections were again very similar to those provided in the paper study report, ${ }^{7}$ and resulted in ten glass compositions for study. The $\mathrm{U}_{3} \mathrm{O}_{8}$ and $\mathrm{ThO}_{2}$ components were removed from the target compositions to support nonradioactive experiments. The target compositions of the KT04-series glasses are available in detail elsewhere. ${ }^{8}$

\section{Glass Fabrication}

Each of the study glasses was prepared from the proper proportions of reagent-grade metal oxides, carbonates, and boric acid in $200 \mathrm{~g}$ batches. The raw materials were thoroughly mixed and placed into platinum/gold, $250 \mathrm{ml}$ crucibles. The batch was placed into a high-temperature furnace at the melt temperature of $1150{ }^{\circ} \mathrm{C}$. The crucible was removed from the furnace after an isothermal hold for 1 hour. The glass was poured onto a clean, stainless steel plate and allowed to air cool (quench). Approximately $25 \mathrm{~g}$ of each glass was heat-treated to simulate cooling along the centerline of a DWPF-type canister ${ }^{9}$ to gauge the effects of thermal history on the product performance. This cooling schedule is referred to as the CCC heat treatment.

\section{Characterization}

Two dissolution techniques, sodium peroxide fusion (PF) and lithium-metaborate fusion (LM), were used to prepare the glass samples, in duplicate, for chemical composition analysis. Each of the samples was analyzed, twice for each element of interest, by Inductively Coupled Plasma - Atomic Emission Spectroscopy (ICP-AES). Glass standards were also intermittently measured to assess the performance of the ICPAES instrument over the course of these analyses. Representative samples of each quenched and $\mathrm{CCC}$ glass were ground for powder XRD analysis.

The Product Consistency Test (PCT) Method- $\mathrm{A}^{10}$ was performed in triplicate on each KT01, KT03, and KT04-series quenched and CCC glass to assess chemical durability. Also included in the experimental test matrix was the Environmental Assessment (EA) benchmark glass, ${ }^{11}$ the Approved Reference Material (ARM) glass, ${ }^{12}$ and blanks from the sample cleaning batch. Samples were ground, washed, and prepared according to the standard procedure. ${ }^{10}$ Fifteen milliliters of Type-I ASTM water were added to $1.5 \mathrm{~g}$ of glass in stainless steel vessels. The vessels were closed, sealed, and placed in an oven at $90 \pm 2{ }^{\circ} \mathrm{C}$ for 7 days. Once cooled, the resulting solutions were sampled (filtered and acidified), then analyzed by ICP-AES. Normalized release rates were calculated based on the measured compositions using the average of the common logarithms of the leachate concentrations.

The viscosity of select glasses was measured following Procedure A of the ASTM

C 965 standard. ${ }^{13}$ Harrop and Orton high temperature rotating spindle viscometers were 
used with platinum crucibles and spindles. The viscometers were specially designed to operate with small quantities of glass to support measurements of radioactive glasses when necessary. ${ }^{14,15}$ A well characterized standard glass was used to determine the appropriate spindle constants. ${ }^{15,16}$ Measurements were taken over a range of temperatures from 1050 to $1250{ }^{\circ} \mathrm{C}$ in $50{ }^{\circ} \mathrm{C}$ intervals. Measurements at $1150{ }^{\circ} \mathrm{C}$ were taken at three different times during the procedure to provide an opportunity to identify the effects of any crystallization or volatilization that may have occurred during the test.

The liquidus temperatures $\left(\mathrm{T}_{\mathrm{L}}\right)$ of select study glasses were determined using the isothermal heat treatment method. ${ }^{17}$ The temperature profile of the furnace was carefully determined and periodically verified. ${ }^{18}$ All thermocouples and temperature measurement devices were calibrated and periodically verified. A standard glass composition was incorporated into the test glass matrix as a method of verifying the measured data. ${ }^{\text {a }}$ Polished samples of each quenched glass were observed via optical microscopy prior to $\mathrm{T}_{\mathrm{L}}$ measurement to determine whether any preexisting crystals were present. Quenched glasses that were found to contain crystals were excluded from testing. The study glasses were ground, washed, dried, and heat treated in platinum boats with tight fitting lids. The glasses were air quenched after being removed from the furnace, then sectioned and polished for microscopy. Any bulk crystallization that occurred during the isothermal heat treatments was identified by optical microscopy. The procedure was repeated over various temperatures to determine the $\mathrm{T}_{\mathrm{L}}$ to within a narrow range of tolerance.

Liquidus temperatures were determined for the KT01-series glasses. Liquidus temperatures for the KT02-series glasses were not measured due to their unrealistically high $\mathrm{TiO}_{2}$ concentrations. Liquidus temperature measurements for the KT03 and KT04series glasses are not yet complete.

\section{RESULTS AND DISCUSSION}

\section{Homogeneity}

The homogeneity of each glass sample was assessed via XRD. All of the quenched KT01-series glasses were found to be amorphous by XRD. XRD results identified crystallization in compositions KT01-HL and KT01-HF. Composition KT01-HL contained magnetite $\left(\mathrm{Fe}^{2+} \mathrm{Fe}_{2}{ }^{2+} \mathrm{O}_{8}\right)$ and lithium silicate $\left(\mathrm{Li}_{2} \mathrm{SiO}_{3}\right)$. Composition $\mathrm{KT} 01-\mathrm{HF}$ contained magnetite.

All of the KT02-series quenched glasses were amorphous by XRD. The XRD results for the CCC versions of the KT02-series glasses identified crystallization in all of the glasses except for compositions KT02-LA, KT02-LF, KT02-HN, and KT02-HK.

The KT02 compositions were selected to explore the impact of varying the concentrations of the major components of the glass on the retention of $\mathrm{TiO}_{2}$. The XRD results for the KT02 glasses are summarized in Table 2, which offers some insight into the impact of compositional changes on the propensity for titanium to crystallize out of the glass. As mentioned earlier, all of the quenched glasses were XRD amorphous. Titanium-containing crystalline phases formed in all of the compositions except for the low $\mathrm{Al}_{2} \mathrm{O}_{3}$ concentration glass, the low $\mathrm{Fe}_{2} \mathrm{O}_{3}$ concentration glass, the high $\mathrm{Na}_{2} \mathrm{O}$

\footnotetext{
a The glass standard is identified as 'Unknown Glass A' from the Pacific Northwest National Laboratory liquidus temperature round robin study.
} 
concentration glass, and the high $\mathrm{K}_{2} \mathrm{O}$ concentration glass. ${ }^{\mathrm{a}}$ In general, the impacts of these components will need additional investigation before drawing further conclusions (i.e., a larger number of compositions should be fabricated and characterized since the effects of an individual component are likely to be strongly influenced by overall composition).

Table 2. Summary of XRD Results for the KT02-Series Glasses.

\begin{tabular}{|c|c|c|c|}
\hline Glass ID & $\begin{array}{c}\text { Composition } \\
\text { Note }\end{array}$ & $\begin{array}{c}\text { Heat } \\
\text { Treatment }\end{array}$ & XRD Results \\
\hline \multirow{2}{*}{ КТ02-HA } & \multirow{2}{*}{ High $\mathrm{Al}_{2} \mathrm{O}_{3}$} & quenched & amorphous \\
\hline & & $\mathrm{CCC}$ & $\mathrm{LiFeTiO}_{4}$, unidentified phase \\
\hline \multirow{2}{*}{ KT02-LA } & \multirow{2}{*}{ Low $\mathrm{Al}_{2} \mathrm{O}_{3}$} & quenched & amorphous \\
\hline & & $\mathrm{CCC}$ & amorphous \\
\hline \multirow{2}{*}{ КT02-HB } & \multirow{2}{*}{ High $\mathrm{B}_{2} \mathrm{O}_{3}$} & quenched & amorphous \\
\hline & & $\mathrm{CCC}$ & $\mathrm{LiFeTiO}_{4}$, unidentified phase \\
\hline \multirow{2}{*}{ KT02-LB } & \multirow{2}{*}{ Low $\mathrm{B}_{2} \mathrm{O}_{3}$} & quenched & amorphous \\
\hline & & $\mathrm{CCC}$ & $\mathrm{LiFeTiO}_{4}$, unidentified phase \\
\hline \multirow{2}{*}{ KT02-HF } & \multirow{2}{*}{ High $\mathrm{Fe}_{2} \mathrm{O}_{3}$} & quenched & amorphous \\
\hline & & $\mathrm{CCC}$ & $\mathrm{LiFeTiO}_{4}, \mathrm{Fe}_{9} \mathrm{TiO}_{15}$ \\
\hline \multirow{2}{*}{ KT02-LF } & \multirow{2}{*}{ Low $\mathrm{Fe}_{2} \mathrm{O}_{3}$} & quenched & amorphous \\
\hline & & $\mathrm{CCC}$ & amorphous \\
\hline \multirow{2}{*}{ KT02-HL } & \multirow{2}{*}{ High $\mathrm{Li}_{2} \mathrm{O}$} & quenched & amorphous \\
\hline & & $\mathrm{CCC}$ & $\mathrm{LiFeTiO}_{4}, \mathrm{Li}_{2} \mathrm{SiO}_{3}$ \\
\hline \multirow{2}{*}{ KT02-LL } & \multirow{2}{*}{ Low $\mathrm{Li}_{2} \mathrm{O}$} & quenched & amorphous \\
\hline & & $\mathrm{CCC}$ & $\mathrm{LiFeTiO}_{4}$, unidentified phase \\
\hline \multirow{2}{*}{ KT02-HN } & \multirow{2}{*}{ High $\mathrm{Na}_{2} \mathrm{O}$} & quenched & amorphous \\
\hline & & $\mathrm{CCC}$ & amorphous \\
\hline \multirow{2}{*}{ KT02-LN } & \multirow{2}{*}{ Low $\mathrm{Na}_{2} \mathrm{O}$} & quenched & amorphous \\
\hline & & $\mathrm{CCC}$ & $\mathrm{LiFeTiO}_{4}$, unidentified phase \\
\hline \multirow{2}{*}{ KT02-HS } & \multirow{2}{*}{ High $\mathrm{SiO}_{2}$} & quenched & amorphous \\
\hline & & $\mathrm{CCC}$ & Rutile $\left(\mathrm{TiO}_{2}\right)$, Hematite $\left(\mathrm{Fe}_{2} \mathrm{O}_{3}\right)$ \\
\hline \multirow{2}{*}{ KT02-LS } & \multirow{2}{*}{ Low $\mathrm{SiO}_{2}$} & quenched & amorphous \\
\hline & & $\mathrm{CCC}$ & unidentified phase \\
\hline \multirow{2}{*}{ КТ02-HK } & \multirow{2}{*}{ High $\mathrm{K}_{2} \mathrm{O}$} & quenched & amorphous \\
\hline & & $\mathrm{CCC}$ & amorphous \\
\hline
\end{tabular}

XRD results for the KT03-series glasses indicated that all of the quenched glasses were amorphous. The XRD results for the CCC glasses showed that four of the compositions, KT03-LN, KT03-LB, KT03-LL, and KT03-HF, contained magnetite and trevorite $\left(\mathrm{NiFe}_{2} \mathrm{O}_{4}\right)$. Two of the glasses were highly devitrified: KT03-HL contained trevorite $\left(\mathrm{NiFe}_{2} \mathrm{O}_{4}\right)$ and $\mathrm{KT} 03-\mathrm{HA}$ contained magnetite with another unidentified phase.

\footnotetext{
${ }^{a}$ The CCC version of glass KT02-LS contained an unidentified phase that may or may not contain $\mathrm{TiO}_{2}$. Further characterization of this glass is in progress to identify this phase.
} 
XRD results for the KT04-series glasses indicated that all of the quenched glasses were amorphous, as well as all of the CCC versions.

Chemical Composition

A review of the ICP-AES data showed that there were no significant issues with meeting the targeted compositions for each of the study glasses.

\section{Durability}

All of the glasses had normalized leachate for boron (NL [B]) values that were well below the $16.695 \mathrm{~g} / \mathrm{L}$ value of the benchmark EA glass. ${ }^{11}$ No heat treatment effects were seen in any of the three sets of compositions. The predictability of the PCT responses was evaluated using the DWPF durability model. ${ }^{19}$ The predicted PCT values, determined using the measured compositions of the glasses, were compared with the normalized PCT responses. Figure 1 provides plots of the DWPF model for B that relates the logarithm of the normalized PCT value to a linear function of a free energy of hydration term $\left(\Delta \mathrm{G}_{\mathrm{p}}\right.$, in $\mathrm{kcal} / 100 \mathrm{~g}$ glass $)$ derived from both of the heat treatments of the glasses. Prediction limits at a 95\% confidence for an individual PCT result are also plotted along with the linear fits. The EA and ARM results are indicated on these plots as well. All but one of the KT01 glasses fall within the prediction limits of the DWPF model. Glass KT01-HK (the high $\mathrm{K}_{2} \mathrm{O}$ concentration composition) has a PCT response that falls below the lower prediction limit; however, the PCT response of this glass remains considerably lower than that of the benchmark EA glass. All but two of the KT03 glasses fall within the prediction limits of the DWPF model. Glasses KT03-HK and KT03-MK have PCT responses that fall below the lower prediction limit; however, the PCT responses of these glasses remain considerably lower than that of the benchmark EA glass. As seen in the KT01 plot, there is an issue with the predictability of these high $\mathrm{K}_{2} \mathrm{O}$ concentration glasses. However, this lack of model applicability may be of little practical importance since $\mathrm{K}_{2} \mathrm{O}$ concentrations of this magnitude are unlikely for actual compositions to be processed at the DWPF. All of the KT04 glasses fall within the prediction limits of the DWPF model, regardless of compositional view or heat treatment, indicating good predictability for these compositions. 


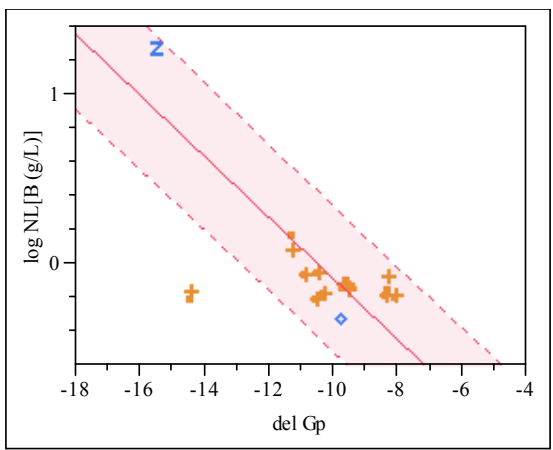

KT01-series

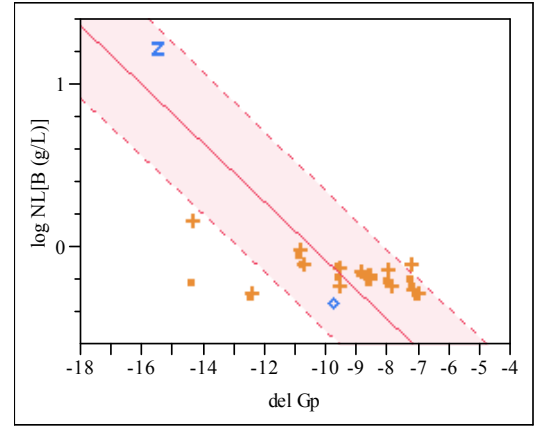

KT03-series

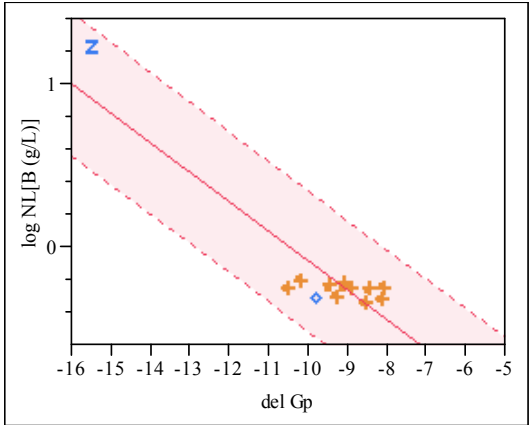

KT04-series

$$
\begin{array}{ll}
\text { z Environmental Assessment Benchmark Glass } & + \text { Quenched Study Glasses } \\
\diamond \text { Approved Reference Material Glass } & \text { Slowly Cooled Study Glasses }
\end{array}
$$

Figure 1. Plots of the DWPF Durability Model Predictions versus Measured PCT Responses for the Three Series of Glasses.

Viscosity

Viscosity data were collected for all of the glasses in the KT01, KT03, and KT04series. The measured viscosity at $1150{ }^{\circ} \mathrm{C}$ was determined by fitting the data for each glass to the Fulcher equation. ${ }^{20,21}$ The results of the Fulcher fits were used to calculate a measured viscosity value for each glass at $1150{ }^{\circ} \mathrm{C}$. The measured values are displayed graphically versus the model predicted values in Figure 2. 


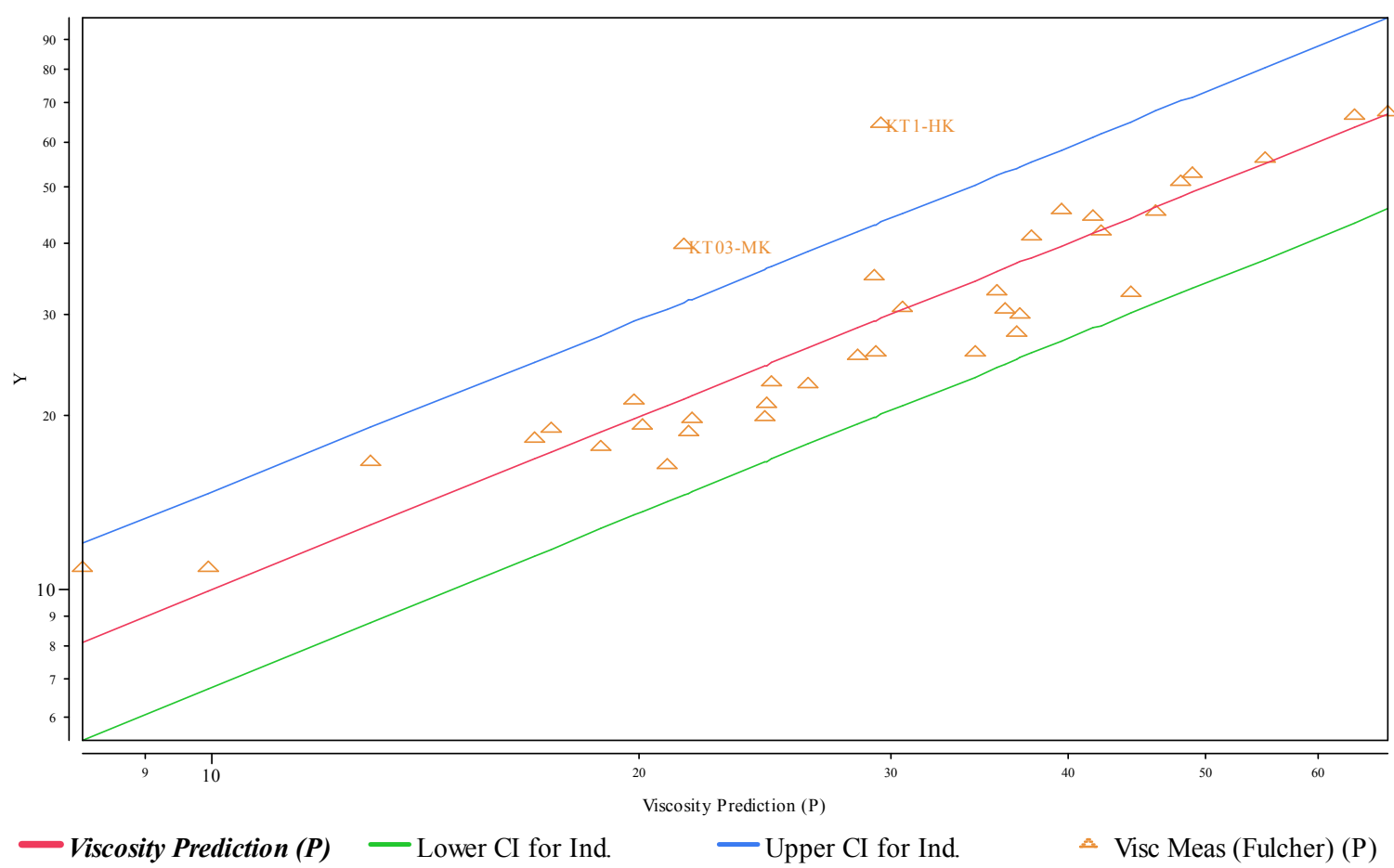

Figure 2. Measured Versus Predicted Viscosities at $1150{ }^{\circ} \mathrm{C}$ for the Three Series of Glasses.

Figure 2 shows that all but two of the study glasses had measured viscosities that were predictable using the current DWPF viscosity model (based on the measured compositions). The two glasses with viscosities that fall above the upper confidence intervals for the model prediction are the high $\mathrm{K}_{2} \mathrm{O}$ concentration glasses KT01-HK and KT03-MK. These glasses have measured $\mathrm{K}_{2} \mathrm{O}$ concentrations of 16.4 and $9.9 \mathrm{wt} \%$, respectively. These concentrations are above the DWPF viscosity model development range 0 to $5.73 \mathrm{wt} \% \mathrm{~K}_{2} \mathrm{O}{ }^{22}$ Interestingly, the $\mathrm{KT} 03-\mathrm{HK}$ composition, with a measured $\mathrm{K}_{2} \mathrm{O}$ concentration of $17.6 \mathrm{wt} \%$, had a measured viscosity that was well predicted by the current DWPF model. While these results point to a lack of applicability for the DWPF viscosity model for increased $\mathrm{K}_{2} \mathrm{O}$ concentrations, it is important to note that these high $\mathrm{K}_{2} \mathrm{O}$ concentration glasses were developed to determine potential impacts of $\mathrm{K}_{2} \mathrm{O}$ on the retention of $\mathrm{TiO}_{2}$ and that their $\mathrm{K}_{2} \mathrm{O}$ concentrations are impractically high for actual DWPF processing. Overall, the measured viscosity values of the KT01, KT03, and KT04-series glasses are well predicted by the current DWPF viscosity model.

\section{Liquidus Temperature}

Liquidus temperatures were measured for the KT01-series glasses. Liquidus temperature estimates for the KT03 and KT04-series glasses are currently underway. Measured liquidus temperatures for the KT01-series glasses are presented in Figure 3 and compared with the predicted values from the DWPF model (based on the measured compositions of the glasses). 


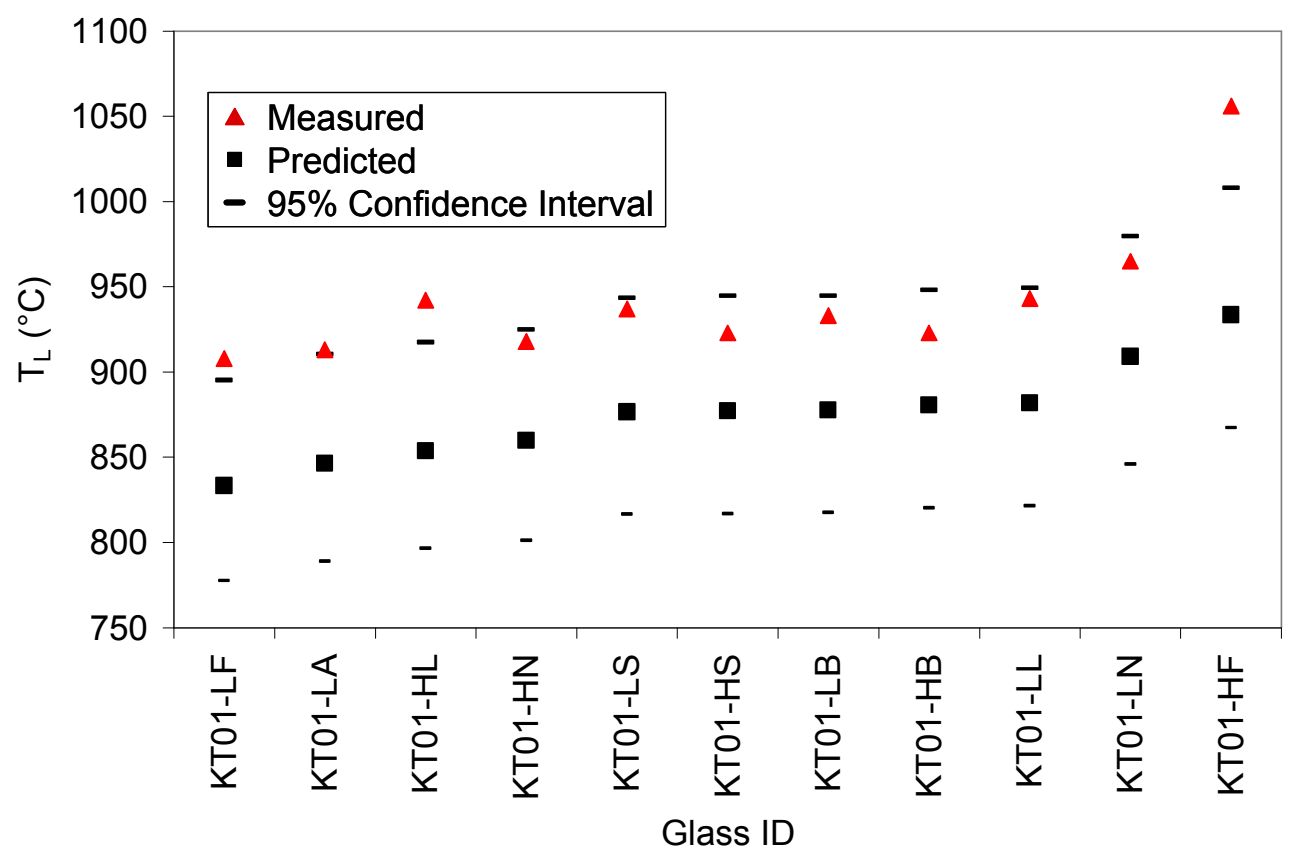

Figure 3. Predicted and Measured Liquidus Temperatures for the KT01-Series Glasses, Based on the Measured Compositions.

The results in Figure 3 are mixed with regard to the predictability of the $T_{L}$ for each glass. All of the measured $\mathrm{T}_{\mathrm{L}}$ values are higher than the model predicted values, although most fall within the 95\% confidence intervals. Compositions KT01-LF, KT01-LA, KT01-HL, and KT01-HF have measured $\mathrm{T}_{\mathrm{L}}$ values that are above the upper 95\% confidence bounds on the predicted values. The concentrations of some of the components in these glasses, particularly $\mathrm{TiO}_{2}$, fall outside the region of applicability of the current $T_{L}$ model. ${ }^{23}$ These results indicate that the model may need to be adjusted in order to more correctly predict the $\mathrm{T}_{\mathrm{L}}$ of glasses when the SCIX streams are incorporated, although further data are necessary (and are currently being collected) for a more complete assessment.

\section{SUMMARY}

Four series of glass compositions were selected, fabricated, and characterized as part of a study to determine the impacts of the addition of CST and MST from the SCIX process on the DWPF glass waste form and the applicability of the DWPF process control models. The KT01 and KT02-series of glasses were chosen to allow for the identification of the influence of the concentrations of major components of the glass on the retention of $\mathrm{TiO}_{2}$. The KT03 series of glasses was chosen to allow for the identification of these influences when higher $\mathrm{Nb}_{2} \mathrm{O}_{5}$ and $\mathrm{ZrO}_{2}$ concentrations are included along with $\mathrm{TiO}_{2}$. The KT04 series of glasses was chosen to investigate the properties and performance of glasses based on the best available projections of actual compositions to be processed at the DWPF (i.e., future sludge batches including the SCIX streams).

The glasses were fabricated in the laboratory without the radioactive components. They were characterized using XRD to identify crystallization, ICP-AES to verify 
chemical compositions, and the PCT to measure durability. The viscosity and liquidus temperature of several of the glasses were also measured.

The XRD results showed no titanium containing phases in the KT01-series glasses, regardless of whether they had been air quenched or slowly cooled. The target $\mathrm{TiO}_{2}$ concentration had to be increased to $12 \mathrm{wt} \%$ in glass in the KT02-series before any compositional impacts on $\mathrm{TiO}_{2}$ retention (e.g., the formation of titanium containing crystals) were apparent. Titanium containing crystalline phases formed in the slowly cooled versions of all of the KT02 compositions except for the low $\mathrm{Al}_{2} \mathrm{O}_{3}$ concentration glass, the low $\mathrm{Fe}_{2} \mathrm{O}_{3}$ concentration glass, the high $\mathrm{Na}_{2} \mathrm{O}$ concentration glass, and the high $\mathrm{K}_{2} \mathrm{O}$ concentration glass. The impacts of these components will need additional investigation before drawing further conclusions (i.e., a larger number of compositions should be fabricated and characterized). However, one should keep in mind that the 12 wt $\% \mathrm{TiO}_{2}$ concentrations in these glasses are unrealistic for DWPF processing with the SCIX streams and material from SWPF. Spinels were identified in some of the KT03 glasses after the $\mathrm{CCC}$ heat treatment. The spinels did not adversely impact the durability of the glasses but will be important for liquidus temperature determinations. The KT04series glasses were amorphous regardless of heat treatment.

All of the glasses studied were considerably more durable than the benchmark EA glass. The measured PCT responses were compared with the predicted values from the current DWPF durability model. One of the KT01-series and two of the KT03-series glasses had measured PCT responses that were outside the lower bound of the durability model. All three of these glasses had intentionally high $\mathrm{K}_{2} \mathrm{O}$ concentrations (to evaluate the impact of $\mathrm{K}_{2} \mathrm{O}$ on $\mathrm{TiO}_{2}$ retention), which may indicate a lack of applicability for the durability model in this composition region. However, this is likely of little practical importance since $\mathrm{K}_{2} \mathrm{O}$ concentrations of this magnitude are unrealistic for actual compositions to be processed at the DWPF. All of the KT04 glasses had durabilities that were predictable regardless of heat treatment or compositional view.

All but two of the KT01, KT03, and KT04-series glasses had measured viscosities that were predictable using the current DWPF viscosity model (based on the measured compositions). The viscosities of two of the high $\mathrm{K}_{2} \mathrm{O}$ concentration glasses, KT01-HK and KT03-MK, fell above the upper confidence intervals for the model prediction. These glasses have $\mathrm{K}_{2} \mathrm{O}$ concentrations that are above the DWPF viscosity model development range for $\mathrm{K}_{2} \mathrm{O}$. Another high $\mathrm{K}_{2} \mathrm{O}$ concentration glass, the KT03-HK composition, had a measured viscosity that was well predicted by the current DWPF model. While these results point to a lack of applicability for the DWPF viscosity model for increased $\mathrm{K}_{2} \mathrm{O}$ concentrations, it is again important to note that these $\mathrm{K}_{2} \mathrm{O}$ concentrations are unrealistic for actual DWPF processing. Overall, the measured viscosity values of the KT01, KT03, and KT04-series glasses are well predicted by the current DWPF viscosity model.

The results of $T_{L}$ measurements for the KT01-series glasses were mixed with regard to the predictability of the $\mathrm{T}_{\mathrm{L}}$ for each glass. All of the measured $\mathrm{T}_{\mathrm{L}}$ values were higher than the model predicted values, although most fell within the $95 \%$ confidence intervals. Compositions KT01-LF, KT01-LA, KT01-HL, and KT01-HF had measured $\mathrm{T}_{\mathrm{L}}$ values that were above the upper $95 \%$ confidence bounds on the predicted values. The concentrations of some of the components in these glasses, particularly $\mathrm{TiO}_{2}$, fall outside the region of applicability of the current $\mathrm{T}_{\mathrm{L}}$ model. These results indicate that the model may need to be adjusted in order to more correctly predict the $\mathrm{T}_{\mathrm{L}}$ of glasses when 
the SCIX streams are incorporated, although further data are necessary for a more complete assessment. Liquidus temperature measurements for the KT03 and KT04series glasses are underway.

\section{FUTURE WORK}

Overall, the results presented in this report show an ability to incorporate the anticipated SCIX streams into the DWPF-type glass compositions studied. Additional experiments are needed to determine whether to extend the validation range of the DWPF process control models or whether refitting of the models will be necessary. Liquidus temperature measurements are continuing for the KT03 and KT04 glasses, and should be performed for any additional compositions developed for this study.

Several additional sets of experimental glasses are being fabricated and characterized to provide further information on potential impacts of the SCIX streams on DWPF glass, including: a study of glass compositions previously shown to crystallize titanium containing phases at lower $\mathrm{TiO}_{2}$ concentrations; a study of glass compositions covering a broader range of potential sludge compositions that remain acceptable for processing by the current DWPF process control models; a study of glass compositions incorporating noble metals that may serve as nucleation sites for titanium containing crystalline phases; and a study of glass compositions containing uranium and thorium that may impact the retention of $\mathrm{TiO}_{2}$ or other glass properties.

At the completion of these studies, all of the data generated will be reviewed with regard to applicability of the DWPF PCCS models and recommendations will be made as to whether the validation ranges of the current models can be extended, or whether some or all of the models need to be refit to allow for the incorporation of the SCIX streams.

\section{REFERENCES}

1. Edwards, T. B., K. G. Brown and R. L. Postles, "SME Acceptability Determination for DWPF Process Control," U.S. Department of Energy Report WSRC-TR-95-00364, Revision 5, Washington Savannah River Company, Aiken, SC (2006).

2. Edwards, T. B. and J. R. Harbour, "Composition and Property Measurements for CST Phase 1 Glasses," U.S. Department of Energy Report WSRC-TR-99-00245, Revision 0, Westinghouse Savannah River Company, Aiken, SC (1999).

3. Edwards, T. B. and J. R. Harbour, "Composition and Property Measurements for CST Phase 2 Glasses," U.S. Department of Energy Report WSRC-TR-99-00289, Revision 0, Westinghouse Savannah River Company, Aiken, SC (1999).

4. Edwards, T. B. and J. R. Harbour, "Composition and Property Measurements for CST Phase 3 Glasses," U.S. Department of Energy Report WSRC-TR-99-00291, Revision 0, Westinghouse Savannah River Company, Aiken, SC (1999).

5. Edwards, T. B. and J. R. Harbour, "Composition and Property Measurements for CST Phase 4 Glasses," U.S. Department of Energy Report WSRC-TR-99-00293, Revision 0, Westinghouse Savannah River Company, Aiken, SC (1999).

6. Edwards, T. B., J. R. Harbour and R. J. Workman, "Summary of Results for CST Glass Study: Composition and Property Measurements," U.S. Department of Energy Report WSRC-TR-99-00324, Revision 0, Westinghouse Savannah River Company, Aiken, $\mathrm{SC}(1999)$. 
7. Fox, K. M., T. B. Edwards, M. E. Stone and D. C. Koopman, "Paper Study Evaluations of the Introduction of Small Column Ion Exchange (SCIX) Waste Streams to the Defense Waste Processing Facility," U.S. Department of Energy Report SRNL-STI2010-00297, Revision 0, Savannah River National Laboratory, Aiken, SC (2010).

8. Fox, K. M. and T. B. Edwards, "Impacts of Small Column Ion Exchange Streams on DWPF Glass Formulation: KT01, KT02, KT03, and KT04-Series Glass Compositions," U.S. Department of Energy Report SRNL-STI-2010-00566, Revision 0, Savannah River National Laboratory, Aiken, SC (2010).

9. Marra, S. L. and C. M. Jantzen, "Characterization of Projected DWPF Glass Heat Treated to Simulate Canister Centerline Cooling," U.S. Department of Energy Report WSRC-TR-92-142, Revision 1, Westinghouse Savannah River Company, Aiken, SC (1993).

10. ASTM, "Standard Test Methods for Determining Chemical Durability of Nuclear Waste Glasses: The Product Consistency Test (PCT)," ASTM C-1285, (2002).

11. Jantzen, C. M., N. E. Bibler, D. C. Beam, C. L. Crawford and M. A. Pickett, "Characterization of the Defense Waste Processing Facility (DWPF) Environmental Assessment (EA) Glass Standard Reference Material," U.S. Department of Energy Report WSRC-TR-92-346, Revision 1, Westinghouse Savannah River Company, Aiken, $\mathrm{SC}(1993)$.

12. Jantzen, C. M., J. B. Picket, K. G. Brown, T. B. Edwards and D. C. Beam, "Process/Product Models for the Defense Waste Processing Facility (DWPF): Part I. Predicting Glass Durability from Composition Using a Thermodynamic Hydration Energy Reaction Model (THERMO)," U.S. Department of Energy Report WSRC-TR-93672, Revision 1, Westinghouse Savannah River Company, Aiken, SC (1995).

13. ASTM, "Standard Practice for Measuring Viscosity of Glass Above the Softening Point," ASTM C-965, (2007).

14. Schumacher, R. F. and D. K. Peeler, "Establishment of Harrop, High-Temperature Viscometer," U.S. Department of Energy Report WSRC-RP-98-00737, Revision 0, Westinghouse Savannah River Company, Aiken, SC (1998).

15. Schumacher, R. F., R. J. Workman and T. B. Edwards, "Calibration and Measurement of the Viscosity of DWPF Start-Up Glass," U.S. Department of Energy Report WSRC-RP-2000-00874, Revision 0, Westinghouse Savannah River Company, Aiken, SC (2001).

16. Crum, J. V., R. L. Russell, M. J. Schweiger, D. E. Smith, J. D. Vienna, T. B. Edwards, C. M. Jantzen, D. K. Peeler, R. F. Schumacher and R. J. Workman, "DWPF Startup Frit Viscosity Measurement Round Robin Results," Pacific Northwest National Laboratory, (Unpublished).

17. "Isothermal Liquidus Temperature Measurement Procedure," Manual L29, ITS0025, Savannah River National Laboratory, Aiken, SC (2009).

18. "Furnace Functional Check," Manual L29, ITS-0096, Savannah River National Laboratory, Aiken, SC (2009).

19. Jantzen, C. M., K. G. Brown, T. B. Edwards and J. B. Pickett, "Method of Determining Glass Durability, THERMO MOdel)," United States Patent \#5,846,278 (1998).

20. Fulcher, G. S., "Analysis of Recent Measurements of the Viscosity of Glasses," Journal of the American Ceramic Society, 8 [6] 339-355 (1925). 
21. Fulcher, G. S., "Analysis of Recent Measurements of the Viscosity of Glasses, II," Journal of the American Ceramic Society, 8 [12] 789-794 (1925).

22. Jantzen, C. M., "The Impacts of Uranium and Thorium on the Defense Waste Processing Facility (DWPF) Viscosity Model," U.S. Department of Energy Report WSRC-TR-2004-00311, Revision 0, Westinghouse Savannah River Company, Aiken, SC (2005).

23. Brown, K. G., C. M. Jantzen and G. Ritzhaupt, "Relating Liquidus Temperature to Composition for Defense Waste Processing Facility (DWPF) Process Control," U.S. Department of Energy Report WSRC-TR-2001-00520, Revision 0, Westinghouse Savannah River Company, Aiken, SC (2001). 